\title{
Genetic variability of microsatellites in autochthonous Podolian cattle breeds in Croatia
}

\author{
Tomislav Keros, Lorena Jemeršić, Jelena Prpić, Miroslav Benić, Besi Roić, Dragan Brnić \\ Croatian Veterinary Institute, Zagreb, Croatia \\ Received February 7, 2012 \\ Accepted April 23, 2013
}

\begin{abstract}
The aim of the study was to analyse the status of the genetic structure of two autochthonous Croatian Podolian breeds (Istrian cattle and Slavonian Syrmian Podolians). The study comprised 20 randomly selected blood samples of each cattle breed. The genotyping was performed on 11 microsatellites (TGLA227, BM2113, TGLA53, ETH10, SPS115, TGLA126, TGLA122, INRA23, ETH3, ETH225, BM1824) as recommended by International Society of Animal Genetics and Food and Agriculture Organization. The procedure enabled the identification of $423(96.14 \%)$ genotypes, indicating the validity of DNA analyses in blood samples and adequacy of the selected microsatellite markers. Likewise, there was the total number of 203 alleles with minimal differences among the studied groups. The differences $(p>0.05)$ were observed within the genotypes of the studied groups regarding the microsatellite loci. The distribution of the genetic relationship was presented by Wright $\mathrm{F}$ coefficients. The $\mathrm{F}_{\mathrm{IS}}$ had negative values for the TGLA 227 locus in both studied groups and for ETH3, ETH225 and BM1834 loci in the Slavonian Syrmian Podolians. This obtained data with relative high values of heterozygosity also shows a genetical influence of other breeds. Almost all $\mathrm{F}_{\mathrm{IT}}$ values were appropriate $(0.31905)$ as a result of excessive selection effects. The mean value of $\mathrm{F}_{\mathrm{ST}}(0.07336)$ indicates that the average degree of genetic variability of the studied breeds was not significantly different despite certain differences in individual loci. The observed specific polymorphism of loci shows that the Istrian cattle and the Slavonian Syrmian Podolians have similar genetic characteristics, but also that there are certain differences between the breeds and even inter-breed differences. The findings indicate a relationship between the breeds and their suitable purity for interbreeding but they also indicate certain danger to certain parts of genome within the studied species. The results can be applied in the protection and breeding programs for the preservation of autochtonous Croatian Podolian breeds.
\end{abstract}

Genetic structure, molecular categorization, Istrian cattle, Slavonian Syrmian Podolians

Today's Podolian cattle are a domesticated sub-species of the original bovine cattle the Bostaurusprimigenus Bojanus Aurochs, Ur. They originate from the highland planes and steppe of the Ukrainian regions of Podolia and Volhinia. About 2000 years ago their herds began moving across Hungary and Romania toward the Danube region and to the south and mid-European regions. During the first centuries of A.D. they were brought to Slavonia and Istria by the Roman legions, and a second wave occurred in the year 452 with the conquests of Attila's hordes. In the millennium to follow, different climate, living conditions and indigenous populations of cattle exerted strong influence on the formation of diverse Podolian breeds that are nowadays present across Romania and Hungary all the way to Slovenia and Italy, and even Spain and North Africa. Two separate breeds have developed in Croatia: the Istrian cattle and the Slavonian Syrmian Podolians, surviving in two relatively distant regions until present times, although unfortunately designated as the "endangered species" by the Food and Agriculture Organization FAO document (Posavi et al. 2003; Ivanković et al. 2006).

The aim of the study was to identify the quality of the selected microsatellite loci, and on the basis of their occurrence, to define the diversities of the two autochthonous Podolian cattle breeds in Croatia: the Istrian cattle and the Slavonian Syrmian Podolians. The analysis includes the status of genetic structures, specific DNA polymorphisms and distribution

Address for correspondence:

Tomislav Keros, PhD

Croatian Veterinary Institute

Savska cesta 143, 10000 Zagreb, Croatia 


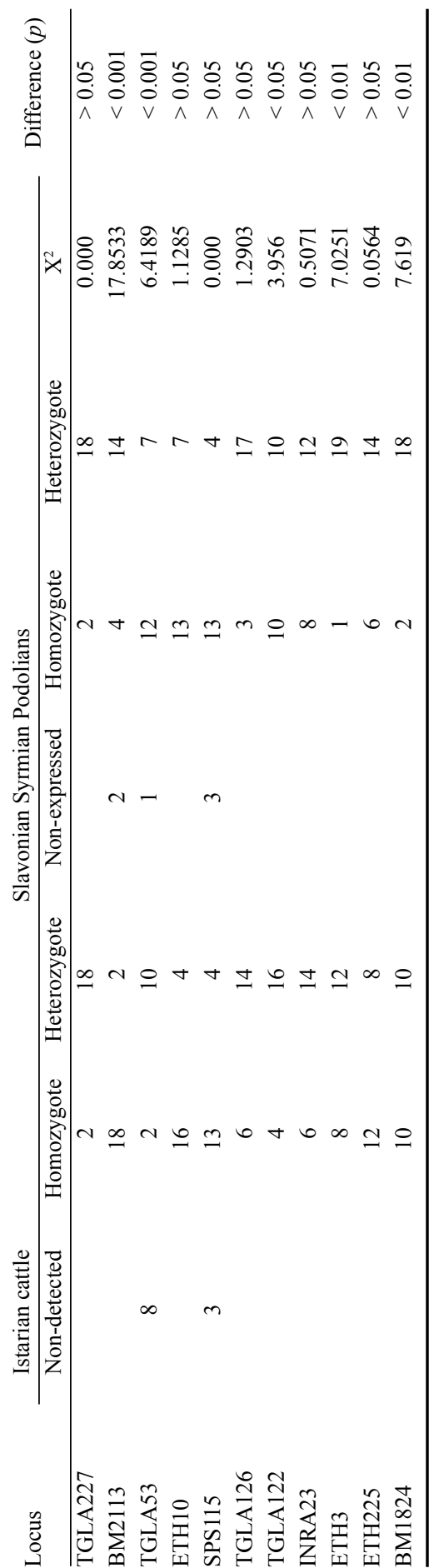

of genetic variability between and within the studied populations, and obtaining baseline data for further, more extensive studies.

\section{Materials and Methods}

The study comprised two populations of randomly selected Podolian cattle originating from breeders that are regularly supervised by veterinary specialists and at the exclusion of closely related animals. The sample included 20 Istrian cattle animals (14 cows and 6 bulls) aged from 4 to 14 years, and 20 Slavonian Syrmian Podolian animals (19 cows and 1 bull), aged from 4 to 10 years.

Blood samples were taken from the jugular vein into Venesect test-tubes with EDTA anticoagulant. The leukocytes were separated in the laboratory by centrifugation using the Nucleospin ${ }^{\circledR}$ Blood (MachereyNagel, Düren, Germany) kit, and pure genomic DNA was separated as described in the guidelines. The genomic DNA was analysed on the basis of 11 microsatellites (TGLA227, BM2113, TGLA53, ETH10, SPS115, TGLA126, TGLA122, INRA23, ETH3, ETH225, BM1824) that were selected from the set within the MoDAD program and proposed by International Society of Animal Genetics and FAO (Bruford et al. 2003; Keros 2009). Amplification of microsatellite sequences was performed by a multiplex procedure Polymerase Chain Reaction (PCR) using commercial stock Marks ${ }^{\circledR}$ Cattle Bovine Paternity PCR Typing Kit (Applied Biosystems, Foster City, Ca USA), and carried out as instructed in the protocols of Gene AMP ${ }^{\circledR}$ PCR System 9700 instrument (Applied Biosystems). Genetic analysis of PCR products was made by capillary electrophoresis in ABI Prism ${ }^{\circledR} 310$ Genetic Analyzer (Applied Biosystems) by using primers for 11 microsattelite loci, linear GS STR POP-4 polymer and DNA controls of the kit (Radko et al. 2005; Rehout et al. 2006; Simčić et al. 2008).

The incidence of microsatellite loci was analysed statistically by ABI Prism Genemapper Software (Applied Biosystems). The significance of differences recorded regarding homozygosity and heterozygosity between and within the observed populations together with the assessment of harmonization of results with Hardy-Weinberg equilibrium principle, was analysed by the standard Chisquare $\left(X^{2}\right)$ test. The test yields a statement of the probability of the obtained distribution having occurred by chance alone (Nei and Kumar 2000; Hartman et al. 2006). Genetic diversity, i.e. coefficients, was determined by Genetix 4.05 program (Kaps and Lamberson 2004).

\section{Results}

In 40 specimens of Podolian cattle, classified by individual breeds, and for the examined 11 microsatellite loci, 423 (96.14\%) genotypes were identified, indicating the validity of blood sample tests as an appropriate source of DNA. Table 1 shows that 8 microsatellite loci occur in all animals (40/40, 100\%). Significant 
differences of homozygosity and heterozygosity in the tested breeds have been found for the loci BM2113 $(p<0.001)$, TGLA53 $(p<0.001)$, TGLA122 $(p<0.05)$, ETH3 $(p<$ $0.01)$ and BM1824 $(p<0.01)$. Successful genotyping also indicates the appropriateness of the microsatellite loci analysed in the study, and that the DNA sequences have been evolutionally preserved which is a fundamental prerequisite for using the individual microsatellites for research purposes.

Table 2. Allelic variability of the observed and the expected heterozygosity in the studied populations of Podolian cattle breeds.

\begin{tabular}{lcccccc}
\hline \multirow{2}{*}{ Locus } & \multicolumn{2}{c}{ Istrian cattle } & \multicolumn{3}{c}{ Slavonian Syrmian cattle } \\
\cline { 2 - 6 } & $\mathrm{H}_{\mathrm{O}}$ & $\mathrm{H}_{\mathrm{E}}$ & Allelic variability & $\mathrm{H}_{\mathrm{O}}$ & $\mathrm{H}_{\mathrm{E}}$ & Allelic variability \\
\hline TGLA227 & 0.947 & 0.886 & 14 & 0.947 & 0.901 & 16 \\
BM2113 & 1.000 & 0.870 & 11 & 0.777 & 0.905 & 15 \\
TGLA53 & 0.833 & 0.888 & 14 & 0.368 & 0.694 & 12 \\
ETH10 & 0.200 & 0.837 & 10 & 0.350 & 0.692 & 10 \\
SPS115 & 0.235 & 0.795 & 8 & 0.588 & 0.847 & 12 \\
TGLA126 & 0.684 & 0.886 & 12 & 0.900 & 0.853 & 12 \\
TGLA122 & 0.850 & 0.940 & 23 & 0.570 & 0.757 & 11 \\
INRA23 & 0.700 & 0.941 & 22 & 0.600 & 0.858 & 14 \\
ETH3 & 0.600 & 0.658 & 9 & 0.950 & 0.803 & 8 \\
ETH225 & 0.400 & 0.673 & 8 & 0.789 & 0.732 & 8 \\
BM1824 & 0.578 & 0.817 & 7 & 0.900 & 0.797 & 11 \\
Total no of alleles* & & & 138 & & & 129 \\
$\bar{X} \pm$ SE & & & $12.55 \pm 1.64$ & & & $11.73 \pm 0.77$ \\
\hline
\end{tabular}

$\mathrm{H}_{\mathrm{O}}$ - observed heterozygosity, $\mathrm{H}_{\mathrm{E}}$ - expected heterozygosity, * total number of alleles per locus, allelic variability - number of alleles per locus

Data are expressed as mean value $\bar{X} \pm \mathrm{SE}$ (standard error)

A total of 203 alleles were defined in the study, with the observed and expected heterozygosity together with the total and mean number of alleles for the tested microsatellite loci presented in Table 2. A minor difference was noted in the mean of the allelic variability between the Istrian cattle $(\bar{X}=12.55$ alleles $)$ and the Slavonian Syrmian Podolians $(\bar{X}=11.73$ alleles $)$. In the studied populations, the highest differences between the total numbers of alleles were found at loci TGLA122 and INRA 23. At both loci, the Istrian cattle showed a significantly larger number of alleles compared to the Slavonian Syrmian Podolian cattle, i.e. 23 alleles vs. 11 alleles at the TGLA122, and 22 alleles vs.14 alleles at the INRA23, respectively. The differences between the allele numbers of other loci were less marked. The Istrian cattle also demonstrated a larger allele number of the loci TGLA53 and ETH3, whereas the allele number of the loci TGLA227, BM2113, SPS115 and BM1824 was shown to be larger in the Slavonian Syrmian Podolian cattle.

In Istrian cattle the greatest variability was observed in locus TGLA122, present with 23 different alleles and heterozygosity of $\mathrm{Ho}=0.85$ and expected heterozygosity of $\mathrm{He}=0.94$. Similar findings were in regards to locus INRA23 with 22 different alleles and $\mathrm{Ho}=0.7 ; \mathrm{He}=0.941$. The smallest variability was observed in BM1824 locus, with seven different alleles and $\mathrm{Ho}=0.578: \mathrm{He}=0.817$. In the Slavonian Syrmian Podolians the greatest variability was exhibited by locus TGLA227, with 16 different 
alleles $(\mathrm{Ho}=0.947, \mathrm{He}=0.901)$. The smallest variability ( 8 different alleles $)$ in the same group of cattle was shown for locus ETH3 $(\mathrm{Ho}=0.95, \mathrm{He}=0.803)$, and locus $\mathrm{ETH} 225(\mathrm{Ho}=0.789, \mathrm{He}=0.732)$.

Regarding the total number of alleles for each individual microsatellite locus analysed, a similarity in the Istrian cattle and Slavonian Syrmian Podolians can be seen in the allelic variability of locus TGLA227, which is extremely variable in both study groups, as well as in the less variable loci ETH10, ETH3 and ETH225. A certain degree of similarity was also observed in loci BM2113, INRA23, SPS115 and TGLA126. The greatest differences in the allelic variability of analyzed loci were noticed between loci ETH3 and ETH225 when compared with locus TGLA227 (Table 2).

Table 3. Distribution of genetic familiarity within the studied groups and differences between them presented by Wright $\mathrm{F}$ coefficients $\left(\mathrm{F}_{\mathrm{IS}}, \mathrm{F}_{\mathrm{IT}}\right.$, and $\left.\mathrm{F}_{\mathrm{ST}}\right)$

\begin{tabular}{lccc}
\hline Locus & $\mathrm{F}_{\text {IS }}$ & $\mathrm{F}_{\text {IT }}$ & $\mathrm{F}_{\mathrm{ST}}$ \\
\hline TGLA227 & -0.03267 & -0.00959 & 0.02235 \\
BM2113 & 0.54460 & 0.56738 & 0.05003 \\
TGLA53 & 0.30657 & 0.38881 & 0.11861 \\
ETH10 & 0.65540 & 0.70270 & 0.13727 \\
SPS115 & 0.52137 & 0.53103 & 0.02020 \\
TGLA126 & 0.11207 & 0.14271 & 0.03451 \\
TGLA122 & 0.22915 & 0.28713 & 0.07521 \\
INRA23 & 0.30127 & 0.33673 & 0.05075 \\
ETH3 & -0.03424 & 0.07463 & 0.10526 \\
ETH225 & 0.18599 & 0.31875 & 0.16309 \\
BM1824 & 0.10477 & 0.13891 & 0.03814 \\
All loci & 0.26514 & 0.31905 & 0.07336 \\
CI (95\%)* & $(0.13653-0.39463)$ & $(0.19364-0.44161)$ & $(0.001104-0.00250)$ \\
\hline
\end{tabular}

*CI $(95 \%)$ - 95\% confidence interval

The distribution of genetic familiarity within the studied groups and differences between them is presented by Wright $\mathrm{F}$ coefficients (Table 3 ). Inbreeding coefficient $\left(\mathrm{F}_{\mathrm{IS}}\right)$ is a measure of deviation of an individual from the Hardy-Weinberg principle and was positive in most loci (Kapš and Lamberson 2004). However, single negative values were obtained in both populations for locus TGLA227, and in Slavonian Syrmian Podolians also for loci ETH3, ETH225, and BM1824. The data indicate the possibility of influence of other breeds, i.e. mating of individuals of different genotypes more often than in incidental mating. Inbreeding coefficient in the total population $\left(\mathrm{F}_{\mathrm{IT}}\right)$ is a measure of total decline of the entire population from the Hardy-Weinberg equilibrium principle, and it showed differed values for almost all loci in our populations with the average value of $\mathrm{F}_{\mathrm{IT}}=0.31905$. A negative value was recorded only for locus TGLA227 (-0.00959), indicating the frequency of mating of genetically non-familiar individuals, or excessive influence of selection. Fixation index $\left(\mathrm{F}_{\mathrm{ST}}\right)$, as a measure of genetic variability between the groups of one population, showed the average value of $\mathrm{F}_{\mathrm{ST}}=0.07336$, meaning that the average degree of genetic variability in the studied groups was not significant. Moderate genetic variability was found for individual loci (BM2113, TGLA53, INRA23, TGLA 122, EH3 and ETH10), whereas high variability was recorded only for locus ETH225. 


\section{Discussion}

Biodiversity has served as the basis for many studies of genetic diversities of domestic animals and livestock worldwide. Special attention has been given to the endangered species, i.e. those showing a rapid decrease of their population. Cattle breeds have also shown a rapid decrease regarding their genetic resources, mostly as a result of raising a relatively small number of highly productive breeds as required by the industrialization of agriculture (Gibson et al. 2007; Slavik et al. 2009). The autochthonous breeds are also being replaced, despite their essential role in the overall animal genetic resources and great economic, scientific, and even historic and cultural values. They have adjusted to specific environmental conditions of local ecological regions through centuries and are today considered a genetic specificity that beside biological diversity contributes to local nutritional safety and sustainability of agricultural systems (Tixier-Boichard et al. 2008).

Studies have shown that the Istrian cattle and their cross-breeds participate in less than $10 \%$ of the total bovine population. Therefore, FAO has put Istrian cattle high on the list of endangered species. In the past few years the situation has improved, and the data for 2005 show $\mathrm{N}_{\mathrm{E}}=90$, at a breeding level of $\Delta \mathrm{F}=0.555$ medium, while the number cows has increased to above 200, at a moderate level of $\Delta \mathrm{F}=0.0175$. The most recent report for 2010 has been stated that there are 508 cows of Istrian Podolian breed in Croatia. Although the Istrian cattle have thus avoided the status of being "critically endangered", the breed is still only partially genetically stable (Ivanković et al. 2006; Distl 2007; Croatian Agricultural Agency 2011).

Today's Slavonian Syrmian Podolian cattle are genetically similar to Istrian cattle. Mild climate, fertile land, and a rich and long farming tradition have contributed to its widespread breeding in Croatian Podravina and Slavonia regions, the prevalence being about $90 \%$ of the total cattle population. The first important genetic studies performed on a nucleus of the Slavonian Podolian showed compatibility of genetic events that determine haemoglobin $(\mathrm{Hb})$ synthesis, with the only difference being that of polymorphism of single alleles on locus for transferine (Tf). However, the difference in the study results concerning the appearance of the gene for haemoglobin synthesis $(\mathrm{Hb})$ in Istrian cattle and transferine (Tf) in the Panonian Podolian can be attributed to the significantly reduced number of these animals (Gašpert et al. 1990; Caput et al. 2004). Slavonian Syrmian Podolians have been included in the program of maintenance and protection only about 10 years ago. According to FAO, classification of the breed is designated as extremely endangered and categorized as "the most vulnerable". In 2005 the number of cows and bulls has been increased, probably due to separating the basic herd into sub-herds, i.e. by formation of new nuclei. According to studies the actual size of Slavonian Syrmian Podolian population was $\mathrm{N}_{\mathrm{E}}=15.06$; however, when the needed correction is made, the number turns out much smaller $\left(\mathrm{N}_{\mathrm{F}}=6.40\right)$, at $\Delta \mathrm{F}=0.0186$ level of in-breeding (Ivanković et al. 2006).

Comparing the obtained results to results of similar studies in other countries, a significantly higher number of different alleles have been found in the observed cattle for the same locus. Moreover, some of the alleles identified in our study do not appear in Bulgarian and Romanian cattle breeds (Teneva et al. 2007; Georgiescu et al. 2009).

The investigation and comparison of microsatellite loci in our studies show their reliability when used as markers in molecular categorization. Specific polymorphisms of individual loci show that the Istrian cattle and Slavonian Syrmian Podolians have familiar genetic peculiarity. At the same time, a certain difference between the breeds and variations within the same breed were recorded. An increased familiarity in the herds of Slavonian Syrmian Podolians should also be pointed out.

The obtained results can be used as initial contribution to future studies of genetic variability between and within the investigated Podolian breeds and can contribute to the 
studies of their phylogeny and even origin. The results can also be applied in practice, particularly as part of the protection and breeding programs concerned with the preservation of autochthonous Croatian Podolian breeds and in genomic map design.

\section{Acknowledgements}

The research was supported by grant No. 048-0481186 from the Ministry of Science, Education and Sports, Republic of Croatia.

\section{References}

Bruford MW, Bradley DC, Luikart G 2003: DNA markers reveal the complexity of livestock domestication. Natur Rev Genet 4: 900-909

Caput P, Ivanković I, Konjačić M 2004: Genome typing of autochtonous breeds of domestic animals in Croatia (croat). Stočarstvo 58: 265-293

Croatian Agricultural Agency 2011: Animal report for 2010- Cattle breeding. CAA, Zagreb

Distl O 2007: Animal genetic data base of the EAAP-AGDB. School of Veterinary Medicine. Hannover. Available at: www.tiho-hannover/deeinrichtzuchteaar descript/11087.htm. Last modified August 10, 2007, Accessed November 6. 2007

Gašpert Z, Caput P, Posavi M 1990: Polymorphism of transpherins and haemoglobin in podolian cattle (croat). Agron Glas 51: 31-36

Georgescu SE, Manea MA, Zeulet M, Costache M 2009: Genetic diversity among Romanian cattle breeds with a special focus on the Romanian grey steppe breed. Rom Biotechnol Lett 14: 4194-4200

Gibson JP, Ayalew W, Hanotte O 2007: Measures of diversity as inputs for decision in conservation of liverstock genetic resources. In: Javis SL, Padock C, Cooper HD (Ed.): Managing biodiversity in agricultural ecosystems. Columbia Univ Press, New York, pp. 117-140

Hartman P, Zajic J, Cech S, Jan Z, Dolezal R 2006: Replacement of the first GnRH administration in the Ovsynch protocol by selecting cows according to the stage of follicular development.Acta Vet Brno 75: 65-72

Ivanković A, Orbanić S, Caput P, Mijić P, Konjačić V, Bulić V 2006: The genetic structure and sustainability of autochthonous cattle breeds in Croatia (croat). Stočarstvo 60: 47-51

Keros T, 2009: Microsatellite loci in Istrian cattle and Slavonian Syrmian Podolian cattle. PhD thesis, Univ Vet Faculty, Zagreb, pp. 61-62

Kaps M, Lamberson WR 2004: Biostatistics for animal science. CABI, Wallingford, Cambridge, 459 p.

Nei M, Kumar S 2000: Molecular evaluation and phylogenetics. Oxford Univ. Press, New York, 339 p.

Posavi M, Ozimec R, Ernoić M, Poljak F 2003: Encyclopedia of Croatian Animals. Zrinski, Varaždin, pp. 51-53

Radko A, Zyga A, Zabek T, Slota E 2005: Genetic variability among Polish Red, Hereford and Holstein- Friesian cattle raised Poland based on analysis of microsatellite DNA sequences. J Appl Genet 46: 89-91

Rehout V, Hradecka E, Čitek J 2006: Evaluation of parentage testing in Czech population of Holstein cattle. Czech Anim Sci 51: 503-509

Simčić M, Čepon M, Horvat S, Jovanović S, Gantner V, Dovč P, Kompan D 2008: Genetic characterisation of autochtonous cattle breeds cika and busha using microsatellites. Acta Agric Slov 92: 71-77

Slavik P, Illek J, Brix M, Musilova L, Rajmon R, Klabanova P, Illek F, 2009: Health Status of beef, cows and their calves in the Czech Republic. Acta Vet Brno 78: 47-56

Teneva A, Todorovska E, Tyufekchiev N, Stella A, Boettcher P, Dimitrov L 2007: Molecular characterisation of Bulgarian livestock genetic resources: II. Microsatellite variation within and among Bulgarian cattle breeds. Biotech Anim Husb 23: 227-242

Tixier-Boichard M, Ayalew W, Jialcin H 2008: Inventory, characterisation and monitoring. AGRI 42: 29-47 